JOURNAL OF AKSARAY COMMUNICATION

Cilt 4, Sayı 1, Ocak 2022 - Volume:4 Issue:1, January 2022

e-ISSN 2667-6168

http://dergipark.gov.tr/aid

Araştırma Makalesi/ Research Article

Doi: 10.47771/aid.1032556

E. (2022). Van Dijkin Eleştirel Söylem Analizi Bağlamında Azerbaycan ve Ermenistan Arasındaki Savaşa İlişkin Le Monde ve Le Figaro'da Kullanılan Haber Başlık ve Girişlerinin Analizi. Aksaray İletişim Dergisi, 4(1), 46-65. doi:10.47771/aid.1032556

\title{
Van Dijk'in Eleştirel Söylem Analizi Bağlamında Azerbaycan ve Ermenistan Arasındaki Savaşa İlişkin Le Monde ve Le Figaro' da kullanılan Haber Başlık ve Girişlerinin Analizi
}

\section{İbrahim Emre GÜNAY ${ }^{1}$}

Öz

Bu çalışmada Fransız gazeteleri Le Monde ve Le Figaro'nun Azerbaycan ve Ermenistan arasında çıkan savaşla ilgili haberleri nasıl sundukları ve olayların haberleştirilirken nasıl kurgulandığı, T.A. Van Dijk'in söylem analizi temel alınarak anlatılmaya çalışılmıştır. Dil ve kullanıldığı bağlam arasındaki ilişki irdelenmiştir ve anlamın değişkenliğine odaklanılmıştır. Bu bağlamda Fransa'da 5 Ekim-19 Ekim 2020 tarihleri arasında çıkan, Le Monde ve Le Figaro'nun çevrim içi arşivleri incelenmiş, T.A. Van Dijk'in söylem analizi temel alınarak Azerbaycan ve Ermenistan arasındaki savaşta kullanılan haber başlık ve girişlerin makro ve mikro yapısal analizi yapılarak, haberin nasıl örtük biçimde bağlamından kopartılarak verildiği gösterilmeye çalışılmıştır.

Anahtar Sözcükler: Van Dijk, Haber, Le Monde, Le Figaro, Söylem

\footnotetext{
1 Öğr. Gör. Dr., Yıldız Teknik Üniversitesi, Yabancı Diller Yüksekokulu, ibrahimemregunay@gmail.com, ORCID: 0000-0003-0657-8164
} 


\title{
Analysis of the News Headlines and Entries Used in Le Monde and Le Figaro on the War Between Azerbaijan and Armenia in the Context of Van Dijk's Critical Discourse Analysis
}

\begin{abstract}
In this study, it has been tried to explain how the French newspapers Le Monde and Le Figaro presented the news about the war between Azerbaijan and Armenia and how the events were fictionalized, based on Van Dijk's discourse analysis. The relationship between language and the context in which it is used has been examined and focused on the variability of meaning. In this context, the online archives of Le Monde and Le Figaro, which were released in France between October 5 and October 19, 2020 were examined and it has been tried to show how the news is given implicitly out of context by making the macro and micro-structural analysis of the news headlines and entries used in the war between Azerbaijan and Armenia based on T.A. Van Dijk's discourse analysis.
\end{abstract}

Keywords:_Van Dijk, News, Le Monde, Le Figaro, Discourse

\section{Giriş}

Azerbaycan ve Ermenistan arasında çıkan savaşla ilgili yapılan haberler başta Le Monde ve Le Figaro gazeteleri olmak üzere Fransız basınında oldukça geniş yer bulmaktadır. Merkez solun ve sağın en önemli temsilcileri olan Le Monde ve Le Figaro gazetelerinde kullanılan Azerbaycan ve Ermenistan savaşıyla ilgili haber başlıkları ve haber girişleri bu çalışmanın inceleme alanını oluşturmaktadır.

Birleşmiş Milletlerin kabul ettiği gibi Dağlık Karabağ, resmi olarak Azerbaycan'a aittir ancak 1991'deki savaştan beri yaklaşık otuz yıldır fiilen Ermenistan'ın işgali altındadır. Bu durumun sonucunda on binlerce Azeri, evlerini ve topraklarını geride bırakarak zorla göç etmek zorunda kalmıştır. 27 Eylül 2020'de Ermenistan'ın sivil yerleşim alanlarına yaptığı füze atışlarıyla savaş yeniden başlamıştır. Bu tarihten itibaren Azerbaycan ve Ermenistan arasındaki savaş haberleri Fransız basınında yer edinmeye başlamıştır.

Eleştirel yaklaşımlar haberi şekillendiren iktidar ilişkilerine, ideolojiye ya da söyleme yoğunlaşmışlardır. Bu yaklaşıma göre haber söylemden ibarettir ve ideolojiden bağımsız olamaz, haber ideolojik bir söylemdir. Medya özellikle kitle iletişim araçları kullanılarak oluşturulan haber, haberin üreticisi ve okuyucusu arasında tek taraflı bir ilişki oluşturur ve yapılan haber ile çıkar odaklarının ya da iktidarın sahip olduğu ideolojisi doğrultusunda okuyucu etkilenmeye çalışılır. Haberin yapımında kullanılan dil hem kendine özgü metinsel özellikler ve yaklaşımlar içerir hem de kendi ve diğer otoriteler arasındaki ilişkilerle betimlenir ve bu ilişkiler iç içe geçmiş 
haldedir. Eleştirel söylem analizi söylemde anlatılmak istenen, saklı olanı ortaya koymaya çalışır. Her söylemin altında gizli olan temel bir düşünce veya ideoloji bulunmaktadır (Eagleton, 2011, s. 257). Söylem analizi bir verici tarafindan belli bir mekân ve zamanda söylenmiş, dil veya dil dişı unsurlardan oluşan, vericinin düşünsel tutumlarını da barındıran ve bazen cümle ötesi birimler olabilen edimler olarak tanımlanabilmektedir (Bozkurt, 2017, s. 373).

Söylem analizinde dil ve kullanıldığı bağlam arasındaki ilişki irdelenir ve anlamın değişkenliğine odaklanılır. Bir anlamda anlamın çeşitliliğini ve değişkenliğini araştıran bir sosyal göstergebilim olarak ele alınabilir. Söylem analizi, disiplinler arası bir yapıya sahip bir analiz türüdür. Tek bir teoriden oluşan ya da bütünsel bir yaklaşım olmanın aksine heterojen özellikli nitel bir yöntemdir. N. Fairclough, G. Kress, T. V. Leuwen, Ruth Wodak ve Teun v. Dijk'1n da içinde bulunduğu bir grup dilbilimci, eleştirel söylem analizinin temel ilkelerini belirlemişlerdir (Büyükkantarcıoğlu, 2012, s. 171). Günümüzde farklı uygulamalarla oldukça sık kullanılan eleştirel söylem analizinin, temel ilkeleri korunarak sosyal bilimler alanındaki çeşitli çalışmalara geniş bir perspektif sunmuştur. 20. yüzyılın ikinci yarısında gelişen sosyoloji, psikoloji, gösterge bilim ve antropoloji gibi alanlar söylem analizinin önemli unsurları olmakla beraber karşılıklı etkilişim halindedirler. Bu duruma bağlı olarak söylem analizinde kullanılan çeşitli yaklaşımlar mevcuttur ve bu yaklaşımlar işaret ettiğimiz bu alanlara bağlı olarak farklılıklar göstermektedir. Haber metinlerinin yapılarını çözümlemeyi amaç edinen eleştirel söylem analizi yöntemi ilgili söylemlerin arkasındaki güç, değer, ideoloji ve kimlik gibi unsurların kurmuş olduğu toplumsal yapının nasıl dilsel kurgular aracılığıla nasıl başka bir yapıya dönüştüğünü ortaya koymaktadır (Doruk, 2013, s. 114).

Bu çalışmada 5 Ekim 2020-19 Ekim 2020 tarihlerinde Le Monde ve Le Figaro gazetelerinde yer alan Azerbaycan ve Ermenistan arasındaki savaşla ilgili haberlerin eleştirel söylem analizi yapılmıştır. Van Dijk'in eleştirel söylem analizi çerçevesinde kullanılan haber başlıkları ve girişleri incelenmiştir. Çalışma Azerbaycan ve Ermenistan arasındaki savaşla ilgili haber başlıklarının ve girişlerinin düz anlamlarının yanı sıra örtük anlamlarının ve savaşın tarafları olan Azerbaycan ve Ermenistan'ın yazılı basında yer alış biçimlerini ortaya koyması açısından önemlidir.

\section{Teun A. Van Dijk'ın Eleştirel Söylem Çözümlemesi Modeli}

Teun van Dijk'in geliştirdiği eleştirel söylem analizi, haber metinlerinde yer alan ideolojik unsurların belirlenen dilsel yapılar içerisine yerleştirildiği ve bunun üzeri örtülü bir şekilde yapıldığını söylerken metnin içinde gizlenmiş ideolojik unsurların eleştirel söylem analiziyle açı̆̆a çıkarılabileceğini vurgulamaktadır. Haber metninin dili eleştirel olarak çözümlenmesi sonucunda haberin söylemindeki ideolojik unsurların ortaya çıkarılmasıyla taraflılığın nasıl yeniden üretildiği de ortaya konulabilmektedir (Özer, 2008, s. 400). Eleştirel söylem çözümlemesi, güç, hâkimiyet, hegemonya, sınıf farkı, cinsiyet, ırk, ideoloji, ayrımcılık, çıkar, kazanç, yeniden inşa, dönüştürme, gelenek, sosyal yapı ya da sosyal düzen gibi temaları ön plana çıkaran 
ve araştırma alanı olarak bu konuları işleyen söylem çözümlemesi yöntemidir (Van Dijk, 2003, s. 355)

İletişim çalışmalarına baktığımızda yapılan haberlerin ideolojiden ve güç ilişkilerinden bağımsız olmadığını ve aslında haberin bir söylemden ibaret olduğunu görebiliriz. Söylem analizi yapılan haberlerin analizinde kullanılan hem en yaygın hem de en önemli yöntemlerden biridir. Söylem analizinin önemli temsilcisi T.A. Van Dijk haber metinlerindeki söylemsel yapının önemine dikkat çekerek haberin ideolojik bir yapı olarak ele alınması gerekliliğini vurgulamaktadır. Haberin söylemi egemen söylemden ayrı düşünülemez ya da bağımsız olamaz (İnal, 1996, s. 97). Haber metinin bağlamı ve güç/iktidar ilişkileri söylem analiziyle ortaya çıkarılabilir.

Van Dijk'in söylem analizi yöntemi haber çözümlemeleri üzerine kurulmuştur (Ülkü, 2004, s. 312). Van Dijk'e göre ideoloji kültürel ortak zeminde paylaşılan zihni temsiller, genel norm ve değerlendirmelerdir. Başka bir deyişle ideoloji gruplar ya da topluluklar tarafından paylaşılan sosyal inançlardır. İktidarların ya da güç odaklarının çıkarları doğrultusunda yapılan haberlerde ele alınan olaylar sosyal inançlar doğrultusunda formüle edilerek okuyucuya içselleştirilir. Olayların haberleştirilmesinde tercih edilen söylem iktidarın yeniden üretilmesiyle ilgilidir. Haber başlıkları, girişleri, fotoğraflar ya da haberin nasıl sunulacağı bir karar aşamasından sonra belirlenmektedir. Güç/iktidar ilişkileri doğrultusunda alınan karaların sonucunda olay haberleştirilerek okuyucuya sunulur. Bir haber metnin söylemediği veya söyleyemediği şeyi görebilmek ya da anlayabilmek için o metnin ötesine gitmek gereklidir (Palmer, 2008, s. 302).

İktidar kitle iletişim araçlarını kullanarak bilginin kontrolünü sağlarken kendi istediği biçimde bilgiyi paylaşır ve bunu yaparken de örtük bir şekilde kendi ideolojisi doğrultusunda başka bir deyişle toplumsal, ekonomik, politik ve kültürel olarak kendi çıkarlarını gözeterek olayları haberleştirir.

Yapılan haberin amacı söylem yoluyla iktidarın ya da egemen gücün ideolojisini okuyucuların içselleştirilebilmesidir. İktidar medyayı kullanarak bir takım yaklaşımlarına meşruluk kazandırmayı hedefler. Kendi çıkarları doğrultusunda politik, kültürel, etnik, sınıf, ırksal ve toplumsal cinsiyet eşitsizlikleri gibi konuları yeniden üretir. Bu nedenden ötürü haber, incelenirken hem iktidarın gözlüğüyle hem de olayın bağlamıyla daha geniş açıdan değerlendirilmelidir. Kitle iletişim araçları güç/iktidar sahiplerinin çıkarları doğrultusunda kamuoyu oluşturur. Sadece güç/iktidar sahiplerini destekleyen konular yapılandırılarak haberleştirilmez, konular belirli biçimlerde oluşturularak, belli sessizlik alanlarını sürdürülerek, güç/iktidar sahiplerinin ana hatlarını verdiği tanımların devam ettirilmesine ve yeniden üretilmesine yardımcı olunur (Özer, 2012, s. 74).

Van Dijk'ın söylem çözümlemesinin temelini makro ve mikro yapılar oluşturmaktadır (Van Dijk, 1988, s. 1-2). Makro yapı analizi tematik ve şematik olmak üzere iki yoldan yapılır. Makro yapı başlı̆̆ı altında başlıklar, haber girişleri ve fotoğraflar tematik analizi oluşturmaktadır. Olayın sunumu, sonuçları, ardalan ve 
bağlam bilgisi, haber kaynakları ve tarafların yorumları şematik analizi oluşturmaktadır. Makro yapı analizinin amacı söylemin neyle ilgili olduğunu ve haberin yazarının ne amaçla haberi ürettiğini anlamaktır. Haberin okunmasından sonra okuyucunun aklında kalan bilginin ne olduğunu açıklar. Başlık ve haber girişleri haberin anlamsal çerçevesinin belirlenmesindeki en önemli unsurlardır (Van Dijk, 2009, s. 69). Makro önermeler enformasyon eksiltimi, genelleştirme ve kurgulama yöntemlerini içermektedir. Başka bir şekilde ifade etmek gerekirse haberi oluşturan başlık ya da haber girişlerinde olayın geçtiği yer ve zaman verilmeyebilir. Genelleştirmeler yapılarak olayın bir takım özelliklerinin üzeri örtülür ve tek bir kavramla olayın bütünü anlatılabilir ya da birbirinden farklı eylemler tek bir eylem ifade edilerek kurgulanarak verilebilir.

Mikro yapı ise sentaktik çözümleme, sözcük seçimleri ve haber retoriğini kapsamaktadır. Mikro yapısal analizin amacı bölümsel anlamların analizidir. Sözcüklerin anlamını, örtük veya dolaylı anlam biçimlerini içermektedir. Böylece haberi yapanın ideolojisi doğrultusunda yapılan seçimin bir işlevi olduğu ve alımlayıcının da duruşunu etkileyen bir bilginin varlığının olduğu gösterilir. Makro ve mikro yapılar alımlayıcının en çok aklında tuttuğu ve yeniden üretilebilen anlamlardir (Van Dijk, 2009, s. 75).

Dilin kullanımı olarak görülen söylem, sözel iletişim ve etkileşim toplumsal düzenin mikro düzeyine aitken, toplumsal gruplar arasındaki iktidar, tahakküm ve eşitsizlik gibi terimler makro çözümleme düzeyine ait olarak değerlendirilmektedir (Evre, 2009, s. 139). Van Dijk haber çözümlemelerinde metni sosyo-bilişsel ve tarihsel arka planıyla bağlantılandırmaktadır. $\mathrm{Bu}$ düşüncesi doğrultusunda haber çözümlemesinin makro ve mikro düzeyleri ile medya metinleri ve bağlamları arasında köprü oluşturmayı amaçlamıştır (Van Dijk, 1988, s. 181). Van Dijk söylem analizinde haber metinlerinin içindeki üzeri örtülü anlam, fikir ve ideolojileri ortaya çıkarmak için bilişsel, sosyal, kültürel ve politik bağlamında analiz edilmesini ve haber metinleri anlamlandirılırken hem haberi yazanin hem de haberin okuyucusunun geçirdiği zihinsel süreçleri başka bir deyişle her iki tarafın bilişsel temsillerini anlamak gerekmektedir. Van Dijk'e göre söylem ve toplum arasındaki ilişkide biliş bir tür aracı görev üstlenmektedir. Söylem yapıları ve toplumsal yapılar birbirlerinden farklıdır ve bu iki farklı yapı arasında zihinsel temsiller bir köprü oluşturmaktadır. Bilişsel bileşen, toplumsal bileşen ve söylem bileşeni Van Dijk'in yaklaşımındaki üç ana unsurdur. Bilişsel bileşen; söylemin üretimiyle ve algılanmasıyla ilgili olan zihin, bellek ve temsillerle ilişkilidir. Toplumsal bileşen; baskın kesimin gücü kötüye kullanımı ve baskı altına alınan kesimin direnişiyle ve aynı zamanda kamu söylemini doğrudan ya da dolaylı olarak etkileyen topluluklarla ilişkili olduğunu ifade etmektedir. Söylem bileşeni söylemin, gücün kötüye kullanımını nasıl yeniden ürettiğinin ya da söylem aracılığıyla baskınlığa nasıl karşı gelindiğinin betimlenerek açıklanmasına yöneliktir (Ercan ve Danış, 2019, s. 546). 
Van Dijk'a göre söylem analizinde şu ilkeler takip edilmelidir.

- Söylem analizinde metin ve konuşmalar incelenir. Bilgiler değiştirilmeden doğal ve gerçeğe yakın bir şekilde incelenir.

- Söylem bağlamdan ayrı düşünülemez. Yer, zaman, sosyal rol, bilgi ve norm gibi bağlamlar incelenmelidir.

- Söylemi meydana getiren kişilerin sosyal yapı içerisindeki konumu incelenmelidir.

- Söylem analizi söylemin düzeyini, katmanlarını ve aralarındaki karşılıklı ilişkileri inceler. Ayrıca söylemi oluşturan öğeler (sesler, kelimeler, sözdizimsel biçimler vb.) ve söylemin değişik boyutlarını da (etkileşim çeşitleri, dil eylemleri) dikkate alınır.

- Söylem analistleri iki soruyu cevaplamaya çalışırlar: "Bunun anlamı ne?" ve “Neden bunu söyledi?".

\section{Le Monde ve Le Figaro Gazetelerinde yer Alan Haber Başlık ve Girişlerinin Makro ve Mikro Yapıya Göre Çözümlenmesi}

Azerbaycan ve Ermenistan arasında çıkan savaş ile ilgili olarak Le Figaro ve Le Monde gazetelerinde yapılan haberler 5 Ekim 2020-19 Ekim 2020 tarihleri esas alınarak incelenmiştir. İncelemede makro yapısal olarak; başlıklar, haber girişleri, olayın sunumu ve sonuçları, ardalan ve bağlam bilgisi, haber kaynakları, mikro yapısal olarak; sentaktik çözümleme, kelimelerin seçimi ve haberin retoriği ele alınmıştır.

\section{Haber Başlıkları}

Le Figaro ve Le Monde gazetelerinin internet haber portallarında Azerbaycan ve Ermenistan arasındaki savaşla ilgili 5-19 Ekim 2020 tarihleri arasında kullanılan haber başlıkları aşağıdaki gibidir:

Başlık 1: Si l'offensive militaire azérie réussit, les Arméniens du Haut-Karabakh seront contraints à l'exode (Azerbaycan askeri saldırısı başarılı olursa, Dağlık Karabağ Ermenileri göç etmeye zorlanacak) (Le Figaro, 6 Ekim 2020, 19:14).

Başlık 2: Plus d'un millier de manifestants à Marseille et Lyon pour soutenir les Arméniens du Nagorny Karabakh (Dağlık Karabağ Ermenilerini desteklemek için Marsilya ve Lyon'da binden fazla gösterici topland1) (Le Figaro, 8 Ekim 2020, 22:48)

Başlık 3: Jean-François Colosimo: «Haut-Karabakh, soutenons les Arméniens et refusons l'indifférence» (Jean-François Colosimo: "Dağlık Karabağ, Ermenileri destekleyin ve ilgisiz kalmayın") (Le Figaro, 11 Ekim 2020, 20:06).

Başlık 4: La «capitale» du Nagorny Karabakh bombardée malgré le cessez-le-feu (Dağlık Karabağ 'başkenti' ateşkese rağmen bombaland1) (Le Figaro, 11 Ekim 00:23).

Başlık 5: Dans les sous-sols de Stepanakert, l'espoir fragile d'un cessez-le-feu (Stepanakert'in bodrum katlarında, kırılgan bir ateşkes umudu) (Le Figaro, 12 Ekim 2020, 20:38). 
Başlık 6: L'impérialisme turc contraint les droits du peuple arménien (Türk emperyalizmi Ermeni halkının haklarını kısıtlıyor) (Le Figaro, 14 Ekim 2020, 15:13).

Başlık 7: L'Arménie accuse l'Azerbaïdjan de violer la trêve (Ermenistan Azerbaycan'1 ateşkesi ihlal etmekle suçluyor) (Le Figaro, 18 Ekim, 2020, 09.06 AM).

Başlik 8: L'Azerbaïdjan se félicite du renfort des drones de son allié turc (Azerbaycan, Türk müttefikinden insansız hava araçlarının güçlendirilmesini memnuniyetle karşılıyor) (Le Monde, 7 Ekim 2020, 11:22).

Başlık 9: Puissance régionale à l'ambition gargantuesque, la Turquie d'Erdogan se moque du Kremlin et de la Maison Blanche (Devasa hirslı bölgesel güç, Erdoğan'ın Türkiye'si Kremlin ve Beyaz Saray'la alay ediyor) (Le Monde, 8 Ekim 2020, 08:26).

Başlık 10: L'Arménie "prête» à reprendre le processus de paix avec l'Azerbaïdjan (Ermenistan, Azerbaycan ile barış sürecini yeniden başlatmaya "hazır") (Le Monde, 9 Ekim 2020, 13:19).

Başlik 11: Malgré le cessez-le-feu, les bombardements continuent (Ateşkese rağmen bombardımanlar devam ediyor) (Le Monde, 11 Ekim 2020, 08:39).

Başlık 12: Les drones, fleurons de l'industrie turque de défense (Türk savunma sanayisinin amiral gemileri olan drone'lar) (Le Monde, 16 Ekim 2020, 11:22).

Başlık 13: Les filières turques de mercenaires syriens en Azerbaïdjan (Azerbaycan'daki Suriyeli paralı askerlerin Türk kanalları) (Le Monde, 18 Ekim 2020, 09:36).

\section{Haber Girişleri}

Haber girişleri ana olay hakkında bilgi vermekte ve olayı özetlemektedir. İncelenen gazete haberlerinin çoğunda haber girişi verildiği görülmektedir. 5-19 Ekim 2020 tarihli haber girişleri aşağıdaki gibidir:

Spot 1: Depuis le 27 septembre, l'Azerbaïdjan a attaqué l'enclave arménienne du Haut-Karabakh et le conflit armé s'étend. Gérard Guerguerian analyse avec précision les différents aspects de ce conflit très préoccupant, dîu notamment au bellicisme d'Erdogan qui soutient Bakou. (27 Eylül'den bu yana Azerbaycan, Dağlık Karabağ'daki Ermeni yerleşim bölgelerine saldırıyor ve silahlı çatışma yayılıyor. Gérard Gergeryan, bu son derece endişe verici çatışmanın çeşitli yönlerini, özellikle de Bakü'yi destekleyen Erdoğan'ın savaş kışkırtıcılığını, hassas bir şekilde analiz ediyor) (Le Figaro, 6 Ekim 2020, 19:14).

Spot 2: Un millier de personnes ont manifesté jeudi soir à Marseille, et environ 300 à Lyon, en soutien aux Arméniens du Nagorny Karabakh, où ont lieu de violents combats avec les forces d'Azerbaïdjan, ont constaté des journalistes de l'AFP. (AFP'li gazeteciler, Azerbaycan güçleriyle yoğun çatışmaların yaşandığı Dağlık Karabağ'daki Ermenileri desteklemek için Perşembe akşamı Marsilya'da bin, Lyon'da ise 300 kişiden oluşan gösteriler düzenlediler) (Le Figaro, 8 Ekim 2020, 22:48). 
Spot 3: Un fragile cessez-le-feu a été conclu entre l'Arménie et l'Azerbaïdjan, qui, aidé par la Turquie, avait lancé une offensive contre les Arméniens du Haut-Karabakh. L'absence de réaction des Occidentaux, Français exceptés, face à l'agression de Bakou soutenue par Ankara a de quoi inquiéter, explique l'historien. (Türkiye'nin de yardımıyla Dağlık Karabağ'daki Ermenilere saldıran Azerbaycan ile Ermenistan arasında her an bozulması mümkün bir ateşkes yapıldı. Bir tarihçi Batı'nın Ankara'nın desteklediği Bakü saldırganlığına karşı tepkisiz kalmasının endişe kaynağı olduğunu söyledi) (Le Figaro, 11 Ekim 2020, 20:06).

Spot 4: Sept lourdes explosions ont été entendues vers 23 h30 locales, faisant trembler le sol dans toute la ville. (Yerel saatle 23:30 sularında şehrin dört bir yanını sallayan yedi ağır patlama duyuldu.) (Le Figaro, 11 Ekim 00:23).

Spot 5: Nombre de brutalités atroces de la Turquie pendant l'histoire ont été ignorées, estime Olivier Delorme. L'historien déplore l'indulgence occidentale à l'égard de l'impérialisme du régime. (Olivier Delorme, tarih boyunca Türkiye'nin birçok acımasız vahşetinin göz ardı edildiğine inanıyor. Tarihçi, Batı'nın rejim emperyalizmine olan hoşgörüsünden üzüntü duyuyor) (Le Figaro, 14 Ekim 2020, 15:13).

Spot 6: Le soutien turc à l'offensive de l'Azerbaïdjan dans le Haut-Karabakh illustre comment une puissance moyenne peut tenir en respect les poids lourds russe et américain. (Azerbaycan'ın Dağlık Karabağ'daki saldırısına Türkiye'nin desteği, orta sıkletin Rus ve Amerikan ağır sıkletlerini nasıl durdurabileceğini gösteriyor) (Le Monde, 8 Ekim 2020, 08:26).

Spot 7: La société privée dirigée par le gendre du président Erdogan fournit une partie des drones utilisés par l'Azerbaïdjan dans le conflit au Haut-Karabakh. (Cumhurbaşkanı Erdoğan'ın damadı tarafından yönetilen özel şirket, Azerbaycan'ın Dağlık Karabağ ihtilafında kullandığı insansız hava araçlarının bir kısmını sağlıyor) (Le Monde, 16 Ekim 2020, 11:22).

Spot 8: La rapidité de l'acheminement de mercenaires syriens par la Turquie vers l'Azerbaïdjan révèle leur intégration, encore plus poussée qu'en Libye, à la projection militaire d'Ankara. (Suriyeli paralı askerlerin Türkiye tarafından Azerbaycan'a gönderilme hızı, Ankara'nın askeri projeksiyonuna Libya'dan daha kapsamlı entegrasyonlarını ortaya koyuyor) (Le Monde, 18 Ekim 2020, 09:36).

\subsection{Haber Başlık ve Girișlerinin Makro Yapıya Göre Değerlendirilmesi}

\subsubsection{Tematik Değerlendirme}

Tematik yapıda başlık, haber girişi ve fotoğraflar incelenmektedir. Başlık ve haber girişi birlikte bir özetleme yapmaktadır (Van Dijk, 1991, s. 114). Birkaç kelimeden oluşan bir haber başlığı uzunca yazılmış bir haber metnini yansıtabilmektedir. Okuyucu haber başlığı sayesinde metinde verilebilecek bilgileri tahmin edebilir ya da bir öngörüde bulunabilir. Van Dijk'a göre haber başlıkları haberi özetlemektedir ve hikaye ederek anlatmaya yaramaktadır (Sözen, 2014, s. 122). Başlıklar, alt başlıklar, spotlar ve haber girişleri incelenirken, haberde yer alan temalar tespit edilir ve bu 
temaların birbiriyle ilişkisini içeren tematik hiyerarşi ortaya çıkarılır (Keskin, 2004, s. 392-393). Tematik yapı haber metninin karmaşık ve ayrıntılı anlam yapısını basite ve genele indirgemektedir.

Yapılan haberlerin genel bir çerçevesini oluşturmak için başlık ve haber girişleri en önemli öğelerdir. Önermeler yapılmak istenen vurguya göre haberin başında ya da sonunda verilmektedir. Haberin başında ilk cümlede vurgu daha fazladır okuyucu metnin kalan kısmını kullanılan ilk cümlenin etkisinde okumaktadır. Haber metnini kontrol eden cümle bu yüzden haberin ilk cümlesidir. Buna göre ana başlık ve haber girişleri okuyucunun haber metnine olan yaklaşımı açısından son derece önemlidir.

Her iki gazetede de kullanılan haber başlıklarında haber yapılan Azerbaycan ve Ermenistan arasındaki savaşı çoğunlukla enformasyon eksiltimi yapılarak bağlamından koparılmış olarak verilmiştir. Başlıklar ve haber girişlerinde kurgulama yapılmıştır. Hem Le Figaro hem de Le Monde kullandıkları başlık ve haber girişleriyle ilgili genel yaklaşımları şu şekildedir:

Hiçbir haber ya da haber girişinde savaşın gerçek nedeni ya da başlatanı bilgisi verilmemektedir. Dağlık Karabağ' tarafından da tanındığı ve ilk saldırının Ermeni birlikler tarafından yapıldığ yok sayılmaktadır. Azerbaycan'ın verdiği kayıplardan söz edilmezken, Ermenistan’a masum ve kendini savunmak zorunda bırakılmış bir ülke imajı verilmektedir. Azerbaycan sürekli bombalayan ve sivillere yönelik saldırlar düzenleyen bir ülke olarak konumlandırılmıştır. Türkiye ve Cumhurbaşkanı Recep Tayyip Erdoğan, kışkırtıcı ve Azerbaycan saldırganlığının arkasındaki güç olarak sunulurken, Türkiye'nin Azerbaycan'ı açıkça insansız hava araçlarını vererek desteklediğini bundan dolayı da Ermenistan'ın desteklenmesi gerekliliğinin altı çizilmektedir. Azerbaycan saldırgan tarafı, Türkiye kışkırtıcı ve Azerbaycan'ın arkasında olan emperyalist destekçisi, Ermenistan ise saldırı altında ve savunmada kalan bir pozisyonda verilmektedir. Yapılan haberlerde Türkiye kimseyi dinlemeyen bir ülke olarak, barışın önündeki engeldir. Fransa'nın Ermenistan'ı desteklediği çok açık olarak yapılan haberlerde ifade edilirken, farklı şehirlerde yapılan Ermenistan'1 destekleyen toplantı ve gösteriler haberleştirilmiştir.

\subsection{2. Şematik Değerlendirme}

Şematik yapıda ana olayın sunumu, sonuç, ardalan bilgisi, bağlam bilgisi, haber kaynakları ve olayın taraflarına odaklanılır. Şematik yapı haberin durum ve yorum bölümlerinden oluşmaktadır. Makro yapı olarak bağlam ve ardalan bilgilerini de içermektedir (Keskin, 2004, s. 392-393). Van Dijk'a göre şema ana olayların sunumu, bağlam, tarih, sözlü tepki ve yorumlardan oluşmaktadır (Sözen, 2014, s. 122). Şematik yapı söylemin genel biçimini ifade etmektedir, haberin üretimini kolaylaştırırken içeriği de düzenlemektedir. Şematik kategoride belirli bir hiyerarşi olmakla beraber bazı kurallar koşullara göre değişkenlik gösterebilir. Genel olarak ilk kategoride başlıklar yer almaktadır. Sonra haber metni ve yorumlar gelebilir. 
Haberi yapılan olayın geçmişi ve bağlamı da olayla ilgili olmasından ötürü ana olayın arkasından sunulabilir.

\section{Olayın Sunumu ve Sonuçları:}

Dağlık Karabağ Birleşmiş Milletlere üye tüm ülkelerin kabul ettiği üzere hukuken Azerbaycan toprağıdır (Anadolu Ajansı) ve Ermenistan 1994 yılında sadece Dağlık Karabağ'a değil çevresindeki Azeri şehirlere de saldırmış ve yaptığı katliamlarla bu yerleri işgal etmiştir. 27 Eylül 2020'de Ermenistan'ın Azerbaycan sınırında gerçekleştirdiği saldırıyla yeni bir savaş başlamıştır. Ermenistan yaptığı füze atışlarıyla birçok sivil Azerbaycan vatandaşının ölümüne neden olmuştur. Azerbaycan ve Ermenistan arasındaki savaş haberleştirilirken her iki gazetede ana olay olarak ele alınan konu sanki Dağlık Karabağ Ermenistan toprağıdır ve Azerbaycan saldırgan, sivilleri bombalayan, ateşkesi sürekli ihlal eden, barış karşıtı, başka bir ülkenin toprağına göz diken bir ülke olarak, Ermenistan ise kendi toprağını savunmaya çalışan, birçok sivil vatandaşının öldüğü, ateşkes yanlısı, barışı arzulayan, haklı taraf olarak sunulmaktadır. Le Figaro ve Le Monde Azerbaycan ve Ermenistan arasındaki savaşta ana olayı Ermenistan'ın bakış açısından sunmaktadır. Yapılan haber başlıkları ve girişlerinde Azerbaycan saldırgan, Türkiye ise Azerbaycan saldırganlığının arkasındaki güç olarak gösterilirken, Ermenistan'a açık bir şekilde destek verilmesi gerektiği belirtilmiştir.

Azerbaycan'ın saldırgan taraf olduğunu ifade eden örnek haber başlikları;

Başlık 1: "Azerbaycan askeri saldırısı başarılı olursa, Dağlık Karabağ Ermenileri göç etmeye zorlanacak" Bu başlıkta Azerbaycan saldırgan olarak gösterilmekle birlikte daha önce 1992-94 yılları arasındaki savaşta yerlerinden edilen Azerilerin yerine yerleşen Ermenilerin tekrar kendi yerlerine dönmeleri durumu zorla göç ettirilme olarak verilmektedir (Le Figaro, 6 Ekim 2020, 19:14).

Başlık 4: "Dă̆lık Karabă̆ 'başkenti' ateşkese rağmen bombalandı" Bu başlikta bombalayan taraf ya da saldırgan taraf isim verilmeden Azerbaycan olarak gösterilmiştir. Üstelik ateşkes olmasına rağmen denilerek Azerbaycan acımasız ve güvenilmez taraf olarak konumlandırılmıştır (Le Figaro, 11 Ekim 00:23).

Başlık 7: "Ermenistan Azerbaycan'ı ateşkesi ihlal etmekle suçluyor" Bu başlikta Azerbaycan'ın ateşkese uymadığının bilgisi verilerek aslında bir suçlama yapılmaktadır (Le Figaro, 18 Ekim, 2020, 09.06).

Başlık 10: "Ermenistan, Azerbaycan ile barış sürecini yeniden başlatmaya hazır" Bu başlıkta barış yanlısı Ermenistan ve sürekli barışı bozan Azerbaycan saldırganlığı karşısında yeniden barış yapmaya hazırdır Ermenistan savunmada ve barış yanlısı bir çizgide tutulmaktadır (Le Monde, 9 Ekim 2020, 13:19).

Türkiye'nin savaş yanlısı olduğunu ifade eden haber başlıkları;

Başlık 6: "Türk emperyalizmi Ermeni halkının haklarını kısıtlıyor" Kullanılan bu başlıkta Türkiye ve Ermenistan karşı karşıya getirilmekte ve Azerbaycan'ın işgal altındaki 
topraklarını savunmasına yardım etmesi emperyalist bir yaklaşım olarak nitelendirilmektedir (Le Figaro, 14 Ekim 2020, 15:13).

Başlık 8: "Azerbaycan, Türk müttefikinden insansız hava araçlarının güçlendirilmesini memnuniyetle karşılıyor" Bu başlıkta insansız hava araçları ile duygu yok edilerek soğuk bir imaj verilmeye çalışılmıştır. Bu durumdan memnun bir Azerbaycan portresi çizilerek Ermenistan üzerinde insanları sempati oluşması sağlanmaya çalışılmıştır. Bu durumun arkasında ise emperyalist ve savaş yanlısı olan Türkiye'ye işaret edilmektedir (Le Monde, 7 Ekim 2020, 11:22).

Başlık 9: "Devasa hırslı bölgesel güç, Erdoğan'ın Türkiye'si Kremlin ve Beyaz Saray'la alay ediyor" Bu başlıkta Türkiye'nin çok önemli bir tehdit olduğuna dikkat çekilmekte ve Cumhurbaşkanı Erdoğan üzerinden Türkiye'nin tüm telkinlere karşı Ermenistan'ın karşısında ve Azerbaycan'ın yanında olacağı Rusya ve ABD ile alay etmesi ifadesiyle verilmektedir. Ayrıca bu başlık hem Rusya hem de Amerika'nın Ermenistan'1 desteklediğinin de göstergesidir (Le Monde, 8 Ekim 2020, 08:26).

Başlik 12: "Türk savunma sanayisinin amiral gemileri olan drone'lar" Bu başlikta Türkiye'nin gösterdiği insansız hava uçaklarının öneminin altı çizilmektedir (Le Monde, 16 Ekim 2020, 11:22).

Başlık 13: "Azerbaycan' daki Suriyeli paralı askerlerin Türk kanalları" Bu başlıkta Türkiye Suriye'nin kuzeyinde Esat güçlerine karşı savaşan güçleri Dağlık Karabağ'da savaşmaları için göndermekle suçlanmaktadır (Le Monde, 18 Ekim 2020, 09:36).

Fransa'nın Ermenistan'ı desteklediğini gösteren haber başlıkları;

Başlık 2: “Dağlık Karabă̆ Ermenilerini desteklemek için Marsilya ve Lyon'da binden fazla gösterici toplandı" (Le Figaro, 8 Ekim 2020, 22:48).

Başlık 3: "Dă̆glı Karabă̆, Ermenileri destekleyin ve ilgisiz kalmayın" (Le Figaro, 11 Ekim 2020, 20:06).

Yukarıda kullanılan başlıklarda Dağlık Karabağ vurgusu yapılarak Ermenistan dışarıda bırakılmaktadır. Savaş Azerbaycan ve Ermenistan arasında sürmektedir ve Dağlık Karabağ tüm dünyanın da kabul ettiği gibi hukuksal olarak Azerbaycan toprağıdır. Ancak açıkça işgal altındaki Azerbaycan toprağı Dağlık Karabă̆'ın desteklenmesi ifade edilmektedir. Marsilya ve Lyon gibi önemli şehirlerdeki destek gösterileri ya da olayın siyasallaştırılması Ermenistan'ın politikalarını meşrulaştırma amacı taşımaktadır.

Azerbaycan'ın saldırgan taraf olduğunu ayrıca Türkiye'nin de Azerbaycan'ın saldırganlı̆̆ını desteklediğini ifade eden haber girişleri;

Spot 1: "27 Eylül'den bu yana Azerbaycan, Dă̆lık Karabă̆g'daki Ermeni yerleşim bölgelerine saldırıyor ve silahlı çatışma yayılıyor. Gérard Gergeryan, bu son derece endişe verici çatışmanın çeşitli yönlerini, özellikle de Bakü'yi destekleyen Erdoğan'ın savaş kışkırtıcılı̆̆ını, hassas bir şekilde analiz ediyor" (Le Figaro, 6 Ekim 2020, 19:14). 
Spot 3: "Türkiye'nin de yardımıyla Dağlık Karabă̆g'daki Ermenilere saldıran Azerbaycan ile Ermenistan arasında her an bozulması mümkün bir ateşkes yapıldı. Bir tarihçi Batı'nın Ankara'nın desteklediğ $i$ Bakü saldırganlı̆̆ına karşı tepkisiz kalmasının endişe kaynă̆ı olduğunu söyledi" (Le Figaro, 11 Ekim 2020, 20:06).

Spot 4: "Yerel saatle 23:30 sularında şehrin dört bir yanın sallayan yedi ă̆ır patlama duyuldu" (Le Figaro, 11 Ekim 00:23).

Spot 6: "Azerbaycan'ın Dağlık Karabağg'daki saldırısına Türkiye'nin desteği, orta sıkletin Rus ve Amerikan ă̆ır sıkletlerini nasıl durdurabileceğini gösteriyor" (Le Monde, 8 Ekim 2020, 08:26).

Fransa'nın Ermenistan'1 desteklediğini gösteren haber girişleri;

Spot 2: “AFP'li gazeteciler, Azerbaycan güçleriyle yoğun çatışmaların yaşandiğı Dağlık Karabağ'daki Ermenileri desteklemek için Perşembe akşamı Marsilya'da bin, Lyon'da ise 300 kişiden oluşan gösteriler düzenlediler" (Le Figaro, 8 Ekim 2020, 22:48).

\section{Ardalan ve Bağlam Bilgisi:}

Ardalan bilgisi, olayların sosyal ve politik yönüne işaret etmektedir. Bir olay haberleştirilirken mutlaka değişime uğramaktadır. Haberi yapan kişinin yorumu haberin o kişinin algısına göre oluşturulmuş olduğunu göstermektedir. Anlam ve ardalan bilgisi genel olarak haberlerde ya eksiltim yapılarak ya da hiç verilmeyerek, haberleştirilen olay kendi bağlamından koparılır ve belirli kalıplar içinde yorum katılarak okuyucuya sunulur. Olayın sosyal, politik ve tarihsel yönünü bilmek olayı anlaşılır kılmakta ve neden sonuç ilişkisi kurarak haberdeki gömülü ideolojinin çıkarılıp anlamlandırılmasını sağlamaktadır (van Dijk, 1988, s. 54).

Ardalan ve Bağlam Bilgisi açısından haberlere bakıldığında, Azerbaycan tarafının Dağlık Karabağ ile ilgili olarak değerlendirmelerine ya da tespitlerine çok az hatta tek bir haberde yer verilmiştir. Genel olarak başlıklarda ve haber girişlerinde yapılan, Ermeni savlarının ve Fransız çıkarlarının ön plana çıkartılarak haberlerin yapılmasıdır. Her iki gazetede de Azerbaycan ve Ermenistan tarafının görüşleri eşit düzeyde verilmemiş, bu durum yapılan haberlerin kullanılan başlık ve haber girişleriyle objektifliğini yok etmiştir.

Kullanılan başlık ve haber girişlerinde yapılan enformasyon eksiltimiyle ilgili olarak şu örnekleri verebilebilir:

1. Ermenistan'ın 1992-1994 yılları arasında, Dağlık Karabağ ve etrafındaki Azeri şehirlerini işgal ederken yaptığı savaş suçları bağımsız uluslararası raporlarla tespit edilmiştir. 27 Eylül'den bu yana, işgal altındaki Azerbaycan topraklarında yaşanan çatışmalarda, yine Ermenistan sivil halkın yaşadığı bölgelere füze atarak masum insanların ölümüne yol açmakta ve savaş suçu işlemektedir. Genel bir inceleme dahi Ermenistan güçlerinin yaşanan 
çatışmalarda birçok uluslararası insancıl hukuk kuralını ihlal ettiğini göstermektedir.

2. 1992 yılında yaşanan savaşta Karabağ Ermeni kuvvetleri Rus ordusunun desteğini de arkasına alarak Azerilerin çoğunluğu oluşturduğu Hocalı kasabasını kuşattılar ve 200'den fazla sivili katlettiler. Bazı kaynaklar bu sayının yaklaşık 1000 civarında olduğunu ifade etmektedir. 1993-94 yıllarında yaşanan savaşta 25 bin insan hayatını kaybederken bir milyondan fazla Azerbaycanlı göç etmek zorunda bırakılmıştır (The Human Rights Watch Report, Azerbaijan: 1994, s. 6). Göç eden Azerbaycanlıların yerlerine Ermenistan da ve başta Lübnan olmak üzere diğer ülkelerde yaşayan Ermeniler yerleştirilmiştir. Her şeylerini geride bırakarak doğdukları yerlerden ayrılmak zorunda bırakılan Azerbaycanlılar tüm geride bıraktıklarına talan ve yağma edilerek el konulmuştur. (The Human Rights Watch Report, Azerbaijan: 1994, s. 35). Bugün binlerce Ermeni'nin göç etmek zorunda kalacağı haberi aslında işgal edilen Azeri topraklarının sahiplerine geri birakılmasıdır.

3. 27 Eylül 2020 tarihinde Ermenistan'ın işgal ettiği Azeri topraklarında Ermeni askerlerce açılan ateş sonucu savaş başlamıştır. Savaş Ermenistan tarafından başlatılmıştır.

4. Resmi beyanlara göre Ermenistan'ın gerçekleştirdiği saldırılarda sadece çatışmaların cereyan ettiği cephe hatlarını değil aynı zamanda Gence, Mingeçevir, Hızı, Şemkir ve Abşeron gibi çatışma bölgesinden uzak şehirler de hedef alınmıştır (Ministry of Foreign Affairs of the Republic of Azerbaijan, Press release: 336/20). Bu yerler sivil yerleşim bölgeleridir ve planlı bir şekilde siviller hedef alınmıştır. 10 Ekim 2020 tarihli ateşkes sonrasında Ermenistan başta Hadrut ve Cebrail olmak üzere sivil yerleşim yerlerini hedef alan saldırılarına devam etmiştir (Ministry of Foreign Affairs of the Republic of Azerbaijan, Press release: 338/20).

5. Resmi beyanlarda Ermenistan'ın Karabağ'da yaşayan Azeri sivilleri bir nevi "etnik temizliğe" tabi tutmaya çalıştığı da yer almaktadır (Ministry of Foreign Affairs of the Republic of Azerbaijan, Press release: 338/20)

6. Ateşkes sonrasında Ermenistan Azerbaycan'ın en büyük ikinci şehri olan Gence'ye roket atarak 9 sivilin ölümüne ve çocuklarda dahil 35 kişiyi yaralamıştır (Ministry of Foreign Affairs of the Republic of Azerbaijan, Press release: $334 / 20)$.

7. 27 Eylül'den 12 Ekim'e kadar geçen sürede Ermeniler tarafından atılan füzeler sonucunda Azerbaycanlı 41 sivil hayatını kaybetmiştir. Sivil yerleşim 
bölgelerinde 70'in üzerinde patlamamış mühimmat bulunmuştur (Haber7, 2020).

\section{Haber Kaynakları:}

Le Figaro ve Le Monde Azerbaycan ve Ermenistan arasındaki savaş haberlerinin önemli bir bölümünü kendi muhabir ve yorumcularına yaptırmış ayrıca Ermenistan vatandaşı gazetecilerden de yararlanmıştır.

\subsection{Haber Başlık ve Girişlerinin Mikro Yapıya Göre Değerlendirilmesi}

\section{Sentaktik Çözümleme:}

Van Dijk'ın çözümleme modelinde sentaktik çözümleme yapılırken cümlelerin uzun-kısa, basit-karmaşık, aktif-pasif durumları incelenmektedir (Van Dijk, 1988, s. 71). Başka bir deyişle sentaktik çözümlemede cümlelerin kullanım yapılarına bakılmaktadır. Aktif ya da pasif yapıyla kurulan bir cümle farklı anlamlar oluşturabilmektedir (Güneş, 2020, s. 22). Haberlerde kullanılan cümlelerde genel olarak basit yapılar kullanılmıştır. Ermenistan ile ilgili haberler aktif yapıda verilmiş böylece haberler Ermenistan'ın bakış açısından ve Ermenistan'ı haklı gösteren bir konumdan verilmiştir.

\section{Kelime Seçimleri:}

Kelime seçimleri, kelimeler aracılığıyla oluşabilecek farklılıklar yoluyla sosyal katılımcılar ve sosyal aktörler hakkındaki temel inançları ve ideolojileri saptayabilir (Van Dijk, 1983, s. 31). Habercilerin kelime kullanımındaki seçimleri farklı anlamları açığa çıkarabilmektedir. Haber metinlerinde olayın kahramanı etken cümle yapısı ya da edilgen cümle yapısı kullanılarak ön plana çıkarılabilir ya da önemsizleştirilebilir. Hedeflenen grubun ya da kişinin eylemleri pasif yapılar kullanılarak örtbas edilebilmektedir. Ayrıca özne konumu ya önemsizleştirilmekte ya da yok edilebilmektedir. Haberi yapılan olayın kaynağının aynı olmasına rağmen farklı kelimelerin kullanımı olayın boyutunu da değiştirebilir. Gazetenin olaya bakışını haber yaparken kullandığı kelimeler ortaya koymaktadır. Tek bir kelime haberi değiştirebilme potansiyeline sahiptir.

Yapılan haberlerde kullanılan başlık ve haber girişlerinde kelimelerin seçimi ideolojik yapılanmanın yönünü de belirlemektedir. İncelenen haberlerde özellikle vurgu yapılan ve sıklıkla kullanılan kelimeler şu şekilde kullanılmıştır; saldırgan, saldırı, bombalama gibi kelimeler haber içinde Azerbaycan ile özdeşleştirilirken, barış yanlısı, ateşkes, siviller gibi kelimeler Ermenistan ile özdeştirilmiştir. Türkiye ve Cumhurbaşkanı Erdoğan için emperyalist ve kışkırtıcı kelimeleri kullanılmıştır.

\section{Haberin Retoriği:}

Haberin retoriğinde ikna edici ve inandırıcı verilere ve bilgilere bakılmaktadır. Görgü tanıklarından yapılan alıntılar, haber retoriğinin bir parçasıdır (Van Dijk, 1991, s. 116). Haber metninde verilen örnekler, benzetmeler, inandırıcı bilgiler haberi okuyucu gözünde ikna edici hala getirmektedir (Güneş, 2020, s. 22). Cümle yapıları, 
sözcük seçimleri, cümleler arasında kurulan nedensellik ilişkileri retorikle ilişkilendirilerek incelenir. Söylemi oluşturan belirleyici kelime ve cümle yapılarının makro düzeyi nasıl yapılandırdığı ve bireysel söylemlerin makro düzeye nasıl taşındığı analiz edilir (Özer, 2011, s. 85). Haber retoriği, haberin nasıl sunulduğunu ifade etmektedir. Haber metninde verilmek istenen ideoloji kullanilan kelime ve cümle yapılarıyla tasarlanarak örtük olarak verilmektedir (Van Dijk, 1988, s. 82). Fotoğraflar, toplumun güvendiği ve toplum içinde saygın bir yere sahip olan kanaat önderlerinin yorumları, kaynak alıntıları, istatistiki bilgiler ikna sürecinin bazı önemli unsurlarıdır ancak bunların kullanılması kadar kullanılmaması ya da yok sayılarak verilmemesi de ikna sürecinin bir parçasını oluşturmaktadır.

Le Figaro ve Le Monde gazetelerinde yapilan haberler hemen hemen hepsi bağlamından kopartılarak sunulmuştur. Haberler hem Fransa'nın bölgedeki çıkarları, hem de Ermenistan'ın çıkarları doğrultusunda ve Azerbaycan'ın hukuki haklılığı ve bu haklılığının uluslararası kurumlarca tespit ve kabul edilmiş olmasına yer verilmeden, yok sayılarak normalleştirici unsurlarla verilmiştir.

\section{Sonuç}

Bu çalışmada 5 Ekim-19 Ekim 2020 tarihleri arasında Fransız gazeteleri Le Monde ve Le Figaro'nun internet baskılarında, Azerbaycan ve Ermenistan arasındaki savaşla ilgili olarak kullanılan haber başlık ve girişleri Van Dijk'in kuramı doğrultusunda makro ve mikro yapısal olarak incelenmiştir. Çalışmada Fransızca olan haber başlıkları ve girişleri Türkçe'ye çevrilerek analiz edilmiştir.

Fransız gazeteleri Le Monde ve Le Figaro'nun ideolojilerini gösteren anlamların nasıl kurulduğu, seçilen sözcükler, kullanılan cümle yapıları üzerinden gösterilmeye çalışılmıştır. Gazeteler sahip oldukları ideoloji doğrultusunda hangi bilgiyi ön plana çıkarmak istiyorlarsa, onun altını çizmektedirler. Karşıt görüş enformasyon eksiltimi yapılarak ve bağlamından koparılarak kurgulanmakta ya da hiç yer verilmeyerek yok sayılmaktadir.

Günümüzde haber tarafsız olarak toplumu bilgilendirme işlevini kaybederek, toplumu iktidarın ya da güç odaklarının çıkarları doğrultusunda etkileyerek yönlendirme amaçlı bir yapıya dönüşmüştür. Kullanılan dilsel yapı insanların dış dünyayı algılaması ve yapılandırması üzerinde belirleyicidir.

Söylemleri aktaran gazetelerin kendilerini ideolojik olarak nasıl konumlandırdıkları haberlerin aktarımında etkin bir role sahiptir. Söylemin ideolojik olarak çerçevelendirilmesi, olayın taraflarının görüşlerine ne kadar sıklıkta yer verilmesi ya da verilmemesi, hangi sözlerin ön sayfada başlık olarak ya da gazetenin iç sayfalarında sıradan, günlük bir olay olarak verileceği gibi kararlar gazetenin taraf olduğu iktidarın ya da güç ilişkilerinin doğrultusunda verilmektedir.

Haberde temsil edilenler Azerbaycan ve Ermenistan'dır. Genel olarak Ermenistan'ın görüşleri haberleştirilirken, Azerbaycanlı yetkililerin demeçlerine oldukça az yer verilmiştir. Burada söylemin hedefi Fransız vatandaşlarıdır. Azerbaycan ve 
Ermenistan arasındaki savaşın haberleştirilmesinde etkilenmesi mümkün Fransız vatandaşların iktidarın istediği doğrultuda olayları algılaması ve yapılandırması hedeflenmektedir.

Her iki gazetede de Azerbaycan ve Ermenistan arasındaki savaş ile ilgili yapılan haber başlık ve girişlerinde enformasyon eksiltimi yapılarak ve haberin bağlamından kopartılarak verildiği ve kurgulama yapıldı̆̆ı görülmüştür. Bu kurgu kendi ideolojik belirlenimlerini güçlendirmek için yapılmaktadır. Bu bağlamda gazeteler gerçeği yeniden üreterek süzgeçten geçirmektedirler.

Azerbaycan ve Ermenistan arasındaki savaşın gerçek nedeni ve başlatan tarafın hangi ülke olduğu kullanılan haber başlıklarında ve girişlerinde verilmemiştir. Dağlık Karabağ'ın Birleşmiş Milletlerin kararı doğrultusunda Azerbaycan toprağı olduğu ve yaklaşık otuz yıldır Ermenistan tarafından işgal edildiği ayrıca ilk saldırının Ermenistan tarafından başlatıldığı bilgisi yok sayılmıştır. Azerbaycan'ın verdiği kayıplardan ya da Ermenistan'ın Azerbaycan şehirlerini bombalamasından söz edilmezken ölüm ya da yaralı haberleri tüm başlık ve haber girişlerinde Dağlık Karabağ'da gerçekleşmiştir. Bu durum haberlerin Ermenistan'ın bakış açısından sunulmasını beraberinde getirirken, yapılan haber girişlerinde Ermenistan'a açı bir şekilde destek verilmesi gerektiği ifade edilmektedir. Ardalan ve bağlam bilgisi açısından haberlere bakıldığında, her iki gazetede de objektif bir yaklaşım gösterilmemiş, Azerbaycan ve Ermenistan tarafının görüşleri eşit düzeyde verilmemiştir. Haberin sunumunda basit ve aktif cümle yapıları tercih edilirken, saldırgan, saldırı, bombalama gibi kelimeler haber içinde Azerbaycan ile özdeşleştirilmiştir. Barış yanlısı, ateşkes, siviller gibi kelimeler Ermenistan ile özdeştirilmiştir. Türkiye için emperyalist ve kışkırtıcı kelimeleri kullanılmıştır.

Bugün Fransa'da yaşayan Ermenilerin sayısının 500 bin olduğu tahmin edilmektedir. Fransa bu rakamla, Rusya ve ABD'den sonra dünyanın en fazla Ermeni uyruklularının yaşadığı üçüncü ülke konumundadır. AB içerisindeki en büyük Ermeni topluluğunu da Fransa'da yaşayan Ermeniler oluşturmaktadır. Fransız basınının Azerbaycan ve Ermenistan arasındaki savaşla ilgili olarak takındığı genel tavırda Ermeni lobisinin çok önemli bir etken olduğu söylenebilir.

Çalışma kapsamında yapılan incelemelerde de Fransa'nın önde gelen gazeteleri olan Le Monde ve Le Figaro'da Azerbaycan ve Ermenistan savaşıyla ilgili haberlerin taraflı olarak yapıldığı açık bir şekilde görülmektedir. Haberler genel anlamda tek yönlü olarak şeffaflıktan uzak ve yanlı bir şekilde sunulmaktadır.

\section{Kaynakça}

Anadolu Ajansı, “Dağlık Karabağ'daki işgale son verilmesini öngören BMGK kararları

uygulanmiyor"https://www.aa.com.tr/tr/azerbaycan-cephe-hatti/daglik-karabag daki-isgale-son-verilmesini-ongoren-bmgk-kararlari-uygulanmiyor/1989110

Erişim tarihi: 17.10 .2020 
Bozkurt, E.S. (2017). Söylem Analizi Bağlamında Saatleri Ayarlama Enstitüsü Romanına Yönelik Bir İnceleme. Atatürk Üniversitesi Türk Dili Ve Edebiyatı Araştırmaları, 371-390.

Büyükkantarcığlu, S. N. (2012). Söylem İncelemelerinde Eleştirel Dilbilimsel Boyut: Eleştirel Söylem Çözümlemesi ve Ötesi. Haberi Eleştirmek, Ed: Ömer Özer, Konya: Literatürk Yayınları.

Çelik, H. ve Ekşï, H. (2013). Söylem Analizi. Marmara University Atatürk Education Faculty Journal of Educational Sciences, 27 (27), 99-117.

Doruk, Ö. (2013). Disiplin Toplumu ve Haber Söylemi: Gökkuşağı Derneği'nce Yapılması Planlanan Yürüyüşün Engellenmesine İlişkin Haberlerin Çözümlenmesi. Gümüşhane Üniversitesi, İletişim Fakültesi Elektronik Dergisi, Sayı: 1(2), 106-132.

Eagleton, T. (2011). İdeoloji. (Çev. Muttalip Özcan), İstanbul: Ayrıntı Yayınları.

Ercan, G. ve Danış, P. (2019). Söylem, Söylem Çözümlemesi ve Eleştirel Söylem Çözümlemesi: Tanımları ve Kapsamları. Dokuz Eylül Üniversitesi Edebiyat Fakültesi Dergisi, $\quad 6 \quad$ (2)

527-552.

https://dergipark.org.tr/tr/pub/deuefad/issue/49601/596349

Evre, B. (2009). Söylem Analizine Yönelik Farklı Yaklaşımlar: Bir Sınıflandırma Girişimi, Medyada Gerçekliğin İnşası Türk Medya Söylemine Eleştirel Bir Bakış içinde, Ed. Parlak İ. Konya: Çizgi Kitabevi.

Güneş, A. (2020). Yazılı Basında Haber Söylemi: 24 Haziran 2018 Cumhurbaşkanlığ1 ve Milletvekili Seçim Haberlerinin Çözümlenmesi. Erciyes Üniversitesi Sosyal Bilimler Enstitüsü Dergisi, XLVIII, 2020/1, 54-75.

Haber7.com, "Son dakika: Ermenistan ateşkesi ihlal etti: Çok sayıda ölü ve yaralı var"https://www.haber7.com/dunya/haber/3022633-son-dakika-ermenistan-atesk esi-ihlal-etti-cok-sayida-olu-ve-yarali-var Erişim tarihi: 11.10.2020

İnal, A. (1996). Haberi Okumak. İstanbul: Temuçin Yayınları.

Keskin, E. Z. (2004). Türkiye'de Haber İncelemelerinde Van Dijk Yöntemi. Haber Hakikat ve İktidar İlişkisi. Dursun Çiler (der.) içinde. Ankara: Kesit Tanıtım. 391-407.

Le Figaro, “Si l'offensive militaire azérie réussit, les Arméniens du Haut-Karabakh seront contraints à l'exode"

https://www.lefigaro.fr/vox/monde/si-l-offensive-militaire-azerie-reussit-les-arm eniens-du-haut-karabakh-seront-contraints-a-l-exode-20201006\#: :text=les\%20aut res $\% 20$ articles-, $\%$ C2\%ABSi\%20l'offensive $\% 20$ militaire $\% 20$ az $\%$ C3\%A9rie $\% 20 r \% C$ 3\%A9ussit $\% 2$ C $\% 201$ es $\% 20$ Arm $\%$ C3\%A9niens $\% 20$ du,seront $\% 20$ contraints $\% 20 \%$ C 3\%A0\%20l'exode $\%$ C2\%BB\&text=FIGAROVOX $\% 2$ FTRIBUNE $\% 20 \% 2$ D $\% 20$ Depuis $\% 201 \mathrm{e} \% 2027, \mathrm{le} \% 20$ conflit $\% 20$ arm $\%$ C3\%A9\%20s'\%C3\%A9tend. Erişim tarihi: 6.10.2020, 19:14 
Le Figaro, "Plus d'un millier de manifestants à Marseille et Lyon pour soutenir les Arméniens du Nagorny Karabakh"

https://www.lefigaro.fr/flash-actu/un-millier-de-manifestants-a-marseille-pour-s outenir-les-armeniens-du-nagorny-karabakh-20201008 Erişim tarihi: 8.10.2020, 22:48

Le Figaro, “Jean-François Colosimo: «Haut-Karabakh, soutenons les Arméniens et refusons l'indifférence" https://www.lefigaro.fr/vox/monde/jean-francois-colosimo-haut-karabakh-souten ons-les-armeniens-et-refusons-1-indifference-20201011 Erişim tarihi: 11.10. 2020, 20:06

Le Figaro, “La «capitale» du Nagorny Karabakh bombardée malgré le cessez-le-feu” https://www.lefigaro.fr/international/la-capitale-du-nagorny-karabakh-bombard ee-malgre-le-cessez-le-feu-20201010 Erişim tarihi: 11.10.2020, 00:23

Le Figaro, "Dans les sous-sols de Stepanakert, l'espoir fragile d'un cessez-le-feu" https:/www.lefigaro.fr/international/haut-karabakh-dans-les-sous-sols-de-stepa nakert-l-espoir-fragile-d-un-cessez-le-feu-20201011 Erişim tarihi: 12.10.2020, 20:38

Le Figaro, "L'impérialisme turc contraint les droits du peuple arménien" https://www.lefigaro.fr/vox/monde/haut-karabagh-l-imperialisme-turc-contraintles-droits-du-peuple-armenien-20201014\#: :text=les\%20autres\%20articles-,Haut\% 2DKarabagh $\% 3$ A $\% 20 \%$ C2\%ABL'imp \%C3\%A9rialisme $\% 20$ turc $\% 20$ contraint,les $\%$ 20droits $\% 20 \mathrm{du} \% 20$ peuple $\% 20$ arm $\%$ C3\%A9nien $\%$ C2\%BB\&text=FIGAROVOX $\% 2$ FTRIBUNE\%20\%2D\%20Nombre\%20de\%20brutalit\%C3\%A9s,de\%20l'imp\%C3\% A9rialisme\%20du\%20r\%C3\%A9gime. Erişim tarihi: 14.10.2020, 15:13

Le Figaro "L'Arménie accuse l'Azerbaïdjan de violer la trêve" https://www.lefigaro.fr/flash-actu/nagorny-karabakh-l-armenie-accuse-l-azerbaid jan-de-violer-la-treve-20201018 Erişim tarihi: 18.10.2020, 09.06

Le Monde, "L'Azerbaïdjan se félicite du renfort des drones de son allié turc" https://www.lemonde.fr/international/article/2020/10/07/haut-karabakh-l-azerbai djan-se-felicite-du-renfort-des-drones-de-son-allie-turc $60551003210 . \mathrm{html}$

Erişim tarihi: 7.10.2020, 11:22

Le Monde, "Puissance régionale à l'ambition gargantuesque, la Turquie d'Erdogan se moque $d u$ Kremlin et de la Maison Blanche" https://www.lemonde.fr/idees/article/2020/10/08/puissance-regionale-a-l-ambitio n-gargantuesque-la-turquie-d-erdogan-se-moque-du-kremlin-comme-de-la-mais on-blanche 6055191 3232.html Erişim tarihi: 8.10.2020, 08:26

Le Monde, “L'Arménie «prête» à reprendre le processus de paix avec l'Azerbaïdjan" 
https://www.lemonde.fr/international/article/2020/10/09/haut-karabakh-une-trev e-possible 6055426 3210.html Erişim tarihi: 9.10.2020, 13:19

Le Monde, "Malgré le cessez-le-feu, les bombardements continuent" https://www.lemonde.fr/international/article/2020/10/11/haut-karabakh-des-bom bardements-armeniens-nocturnes-font-7-morts-en-azerbaidjan 6055607 3210.ht

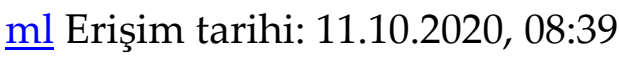

Le Monde, "Les drones, fleurons de l'industrie turque de défense" https://www.lemonde.fr/international/article/2020/10/16/les-drones-fleurons-de-lindustrie-turque-de-defense 6056260 3210.html Erişim tarihi: 16.10.2020, 11:22

Le Monde, "Les filières turques de mercenaires syriens en Azerbaïdjan" https://www.lemonde.fr/blog/filiu/2020/10/18/les-filieres-turques-de-mercenaires -syriens-en-azerbaidjan/ Erişim tarihi: 18.10.2020, 09:36

Ministry of Foreign Affairs of the Republic of Azerbaijan, "No: 334/20, Information of the Press Service Department of the Ministry of Foreign Affairs of the Republic of Azerbaijan on the telephone conversation between the Minister of Foreign Affairs of the Republic of Azerbaijan Jeyhun Bayramov and the Minister of Foreign Affairs of the Kingdom of Saudi Arabia Faisal bin Ferhan Al Saud $(\mathrm{En} / \mathrm{Ru})^{\prime \prime}$, Ministry of Foreign Affairs of the Republic of Azerbaijan, https://mfa.gov.az/en/ news/6946/view Erişim tarihi: 20.11.2020

Ministry of Foreign Affairs of the Republic of Azerbaijan, "No: 336/20, Information of the Press Service Department of the Ministry of Foreign Affairs of the Republic of Azerbaijan on the telephone conversation between the Minister of Foreign Affairs Jeyhun Bayramov and Ivan Korčok, the Minister of Foreign and European Affairs of the Slovak Republic (En/Ru)" https://www.mfa.gov.az/en/news/6948/view Erişim tarihi: 20.11.2020

Ministry of Foreign Affairs of the Republic of Azerbaijan, "No: 338/20, Information of the Press Service Department of the Ministry of Foreign Affairs of the Republic of Azerbaijan on the meeting of Foreign Minister Jeyhun Bayramov with the newly appointed Ambassador of the Kingdom of the Netherlands" https://www.mfa.gov.az/en/news/6950/view Erişim tarihi: 20.11.2020

Özer, Ö. (2008). İdeolojik Atmosferin Kapsama Alanı: Bozüyük Olaylarının Ortadoğu ve Ülkede Özgür Gündem Gazetelerinde Sunumu Örneğinde Haber Söyleminde Yapılan İdeolojik Üretime İlişkin Yeni Bir Çözümleme. Türkiye'de Sivil İtaatsizlik Toplumsal Hareketler ve Basın (Der: E. Dağtaş). Ankara: Ütopya Yayınevi.

Özer, Ö. (2011). Haber Söylem İdeoloji, Eleştirel Haber Çözümlemeleri, Konya: Literatürk Yayınları.

Özer, Ö. (2012). Teun Van Dijk Örneğinde Eleştirel Söylem Çözümlemeleri, Ö. Özer (Ed.) Haberi Eleştirmek, Konya: Literatürk. 
Palmer, R.E. (2008). Hermenötik. (Çev. İbrahim Görener), İstanbul: Ăgaç Kitabevi Yayınları.

Sözen, E. (2014). Söylem Belirsizlik, Mübadele, Bilgi/Güç ve Rafleksivite. Ankara: Birleşik Yayınevi.

The Human Rights Watch Report, Azerbaijan: Seven Years of Conflict in Nagorno-Karabakh(1994),https://www.hrw.org/reports/AZER\%20Conflict\%20in \%20N-K\%20Dec94 0.pdf Erişim tarihi: 26.11.2020

Ülkü, G. (2004). Söylem Çözümlemesinde Yöntem Sorunu ve Van Dijk Yöntemi, Haber Hakikat ve İktidar İlişkisi, Der: Ç. Dursun, Ankara: Elips Yayınları.

Van Dijk, T. A. (1983). Discourse Analysis: Its development and application to the structure of news. Journal of Communication, 33 (2), 20-43.

Van Dijk, T.A. (1988). News As Discourse. New Jersey: Lawrence Erlbaum Associates Publishers.

Van Dijk, T. A. (1991). The Interdisciplinary Study of News as Discourse. A Handbook of Qualitative Methodologies for Mass Communication Research, K. B. Jensen (Ed.) ve N. W. Jankowski, Routledge. 331-395.

Van Dijk, T. A. (2003). Critical Discourse Analysis. D. Schiffrin., D. Tannen, \& E., H. Hamilton. (Ed.), In The Handbook of Discourse Analysis, Oxford: Blakwell Publishing.

Van Dijk, T. (2009). Critical Discourse Studies: A Sociocognitive Approach, In Ruth Wodak \& Michael Meyer (Eds.), Methods of Critical Discourse Analysis, London: Sage. 